NEBOJŠA STAMBOLIJA, istraživač-pripravnik Institut za savremenu istoriju

\title{
OFICIRSKI KOR SRPSKE DRŽAVNE STRAŽE ${ }^{*}$
}

APSTRAKT: Tema rada je analiza oficirskog kora Srpske državne straže. Na osnovu dosijea oficira predstavlja se njihova struktura po nacionalnosti, veri, mestu rođenja, školovanju, rodu kojem pripadaju, bračnom i porodičnom stanju. Takođe, hronološki se prati njihovo brojno stanje i struktura po činovima, a navedena su i lična primanja. Na kraju su dati izvodi iz nekoliko članaka ideološko-etičkog karaktera koji su objavljeni u Glasniku Srpske državne straže. U zaključku je podvučeno stanovište, potkrepljeno izvornom građom, da je velika većina pripadnika oficirskog kora Srpske državne straže bila simpatizer, pripadnik ili prikriveni saradnik Jugoslovenske vojske u otadžbini. Rad je napisan na osnovu izvorne (Vojni arhiv) i objavljene građe, odgovarajuće periodike i literature.

KLJUČNE REČI: oficiri, stražari, Srpska državna straža, Drugi svetski rat, okupacija, Nemci, Jugoslovenska vojska u otadžbini, Srbija, Milan Nedić

Početkom 1942. godine, a zbog potrebe efikasnijeg kontrolisanja teritorije okupirane Srbije, dolazi do reorganizacije bezbednosno-obaveštajnog aparata nemačke okupatorske sile. Od Više komande za naročitu upotrebu i Štaba vojnoupravnog komandanta stvorena je institucija Komandujućeg generala i vojnog zapovednika, koju je funkciju vršio general Paul Bader. Operativna grupa policije (Sicherheitspolizei - SiPo) i nacistička obaveštajna služba (Sicherheitsdienst SD) spojene su, a na čelo nove institucije (Zapovednik policije sigurnosti i službe bezbednosti - Befehlshaber der Sicherheitspolizei und der Sicherheitsdienst BDS) došao je pukovnik Emanuel Šefer. Tokom februara u Srbiju dolaze i četiri puka policije poretka, a tim formacijama (Ordnungspolizei - OrPo) komandovao je potpukovnik Andreas Mej (Befehlshaber der Ordnungspolizei - BDO). Dolaskom SS generala Augusta Majsnera i stavljanjem pod njegovu komandu policijskog i

* Rad je deo projekta Srpsko društvo u jugoslovenskoj državi u 20. veku: između demokratije i diktature (177016), koji finansira Ministarstvo prosvete, nauke i tehnološkog razvoja Republike Srbije. 
obaveštajnog aparata (BDS i BDO), početkom februara, dovršava se proces reorganizacije. ${ }^{1}$

U skladu sa novonastalim promenama ukazuje se i potreba za reorganizacijom oružanih snaga „Vlade narodnog spasa“. Na sastancima kod generala Milana Nedića dogovoreno je da se nova formacija zove Srpska državna straža. Uredba o ustrojstvu je objavljena 3. marta 1942. Po toj uredbi, SDS je bila definisana kao uniformisana i oružana trupa koja vrši policijsku izvršnu i graničnu službu. U njen sastav uključeni su pripadnici dotadašnje žandarmerije, policijske straže, oružanih odreda i pogranični organi finansijske kontrole. Pripadnici SDS su bili u službi Ministarstva unutrašnjih poslova. Srpska državna straža se delila na: 1) gradsku državnu stražu, koja je vršila službu u Beogradu i drugim gradovima, 2) poljsku državnu stražu, koja je vršila službu na celoj teritoriji zemlje osim na područjima gradskih straža i 3) graničnu stražu, koja je vršila graničnu službu. Na teritoriji grada Beograda je, kao posebna jedinica koja je bila direktno podređena upravniku grada Beograda, službu vršila Srpska državna straža Uprave grada Beograda. Na čelu SDS je bio komandant, koji je sa štabom sačinjavao Komandu SDS. Dalje, teritorijalnom podelom SDS je bila podeljena na okružne (gradske), a ovi na sreske (kvartne) odrede. Sreski su se dalje delili na potreban broj staničnih odeljenja. ${ }^{2}$

Navedenom uredbom o ustrojstvu kandidati za stupanje u oficirski kor morali su ispunjavati nekoliko uslova: da su srpske narodnosti i čisto arijevskog porekla; da su navršili 18 i nisu prekoračili 30 godina života; da su telesno i duševno zdravi; da su neoženjeni, udovci bez dece ili zakonski razvedeni od žene bez dece; da su besprekornog vladanja; da imaju najmanje srednju školsku spre$\mathrm{mu}$; da su visoki najmanje $168 \mathrm{~cm}$ (za poljsku stražu), $169 \mathrm{~cm}$ (za gradsku stražu), odnosno $170 \mathrm{~cm}$ (za prijem u Srpsku državnu stražu Uprave grada Beograda). Međutim, u određenim situacijama ministar unutrašnjih poslova ${ }^{3}$ je, na predlog komandanta SDS, mogao eventualne kandidate za prijem osloboditi svih uslova osim da su duševno i telesno zdravi i da imaju čisto arijevsko poreklo.

Ukoliko im nije priznat raniji čin odnosno položajna grupa, oficiri su počinjali službu sa činom potporučnika-pripravnika državne straže X ili, ako je u pitanju lice sa fakultetskom diplomom, IX položajne grupe. U zavisnosti od školovanosti trajala je i pripravnička služba. Tako je ona za kandidate sa fakultetskom spremom trajala godinu dana, sa srednjom školskom spremom dve i za sve ostale tri godine. ${ }^{4}$

\footnotetext{
${ }^{1}$ Milan Borković, Kontrarevolucija u Srbiji. Kvislinška uprava 1941-1944, knj. 1, Beograd 1979, 286.

${ }^{2}$ Službene novine, 3. mart 1942, 1; M. Borković, n. d., knj. 1, 287-290; Bojan B. Dimitrijević, Vojska Nedićeve Srbije, Beograd 2011, 155-158.

${ }^{3}$ Ingerencije po ovom pitanju prvenstva u komandovanju od ministra unutrašnjih poslova preuzima, nakon avgusta 1942, šef Srpske državne bezbednosti.

${ }^{4}$ Službene novine, 3. mart 1942, 4-5.
} 
Iako je SDS formirana 3. marta 1942, zvanično prevođenje oficira u kor Srpske državne straže desilo se tek početkom oktobra 1942. godine. Tada se skoro čitav sastav oficirskog kora našao u dnevnim novinama Novo vreme i tom prilikom su im određene položajne grupe. U isto vreme regulisan je i status Srpske granične straže koja je izdvojena iz SDS i od nje stvorena posebna vojna formacija. ${ }^{5}$ Tom prilikom im se obratio Dragi Jovanović, šef Srpske državne bezbednosti, $^{6}$ kao najviši pretpostavljeni starešina. On im je čestitao stupanje u kor oficira istakavši da „Srpska državna straža na čelu sa vama mora vašim sopstvenim snagama da zagarantuje mir, red i bezbednost i spreči narušavanje tih neophodnih tekovina srpskom narodu, od sviju onih koji bi to pokušali da naruše". Takođe im je savetovao da „sa okupatorskim vlastima i posadama na teritoriji Srbije“ održavaju „najkorektnije i najlojalnije odnose“ i da se ne obaziru na „demonske glasove koji kroz etar traže nove i nove hiljade mrtvih srpskih glava“".

Činjenica da je veliki broj vojnih obveznika sa prostora okupirane Srbije, uključujući i aktivne oficire, otišao u nemačko zarobljeništvo nakon Aprilskog rata, ${ }^{8}$ mnogostruko je uticala na strukturu i karakter komandnog kadra Srpske državne straže, kao i uostalom svih vojnih formacija koje su postojale na prostoru okupirane Srbije.

Na osnovu dosijea oficira Srpske državne straže koji se čuvaju u Vojnom arhivu izvršili smo analizu oficirskog kora. ${ }^{9}$

${ }^{5}$ Uredba o Srpskoj graničnoj straži je donesena na sednici Vlade narodnog spasa 16. oktobra 1942, a objavljena 20. oktobra 1942. Tom Uredbom SGS se izdvaja iz Srpske državne straže i potčinjava se direktno ministru finansija. - Službene novine, 20. oktobar 1942.

${ }^{6}$ Uredba o obrazovanju celokupne Službe srpske državne bezbednosti donesena je na sednici Vlade narodnog spasa 10. avgusta 1942, a objavljena 25. avgusta 1942. U nadležnost SDB potpadale su Komanda Srpske državne straže, Odeljenje za državnu zaštitu, Odeljenje za javnu bezbednost, kao i sve državne policijske vlasti u zemlji. - Službene novine, 25. avgust 1942.

${ }^{7}$ Glasnik Srpske državne straže, broj 4, 1942, 301-302.

${ }^{8}$ Nakon završetka operacija u kratkotrajnom Aprilskom ratu u nemačkom zarobljeništvu je, prema najranijim nemačkim službenim podacima, završilo 6.298 oficira i 337.864 podoficira i vojnika, dok je u italijanskom zarobljeništvu završilo još oko 30.000 vojnika (Jozo Tomasevich, Četnici u Drugom svjetskom ratu, Zagreb 1979, 78). Posle puštanja vojnika hrvatske nacionalnosti, sa prostora južne Srbije (koji su smatrani Bugarima), iz Crne Gore, pripadnika manjina, a kasnije i nekih Srba sa prostora Nezavisne Države Hrvatske, u zarobljeništvu je, prema procenama Velimira Terzića ostalo oko 210.000 ljudi, od čega 10.000 u italijanskom. Od tog broja 90\% su bili Srbi, a ostatak većinom Slovenci i Jevreji (Slom Kraljevine Jugoslavije. Uzroci i posledice poraza, knj. 2, Beograd 1983, 470-472). Prema posleratnim procenama, na osnovu analize popisa žrtava rata, u zarobljeništvu je bilo između 242.037 i 255.004 jugoslovenskih državljana (Dragan Cvetković, „Stradanje pripadnika vojske Kraljevine Jugoslavije iz Hrvatske u zarobljeničkim logorima“, Dijalog povjesničaraistoričara, br. 8, Zagreb 2004, 375).

${ }^{9} \mathrm{Za}$ analizu su korišćena 664 dosijea koja se čuvaju u kutijama 141, 142 i $143 \mathrm{u}$ fondu Nedićeva arhiva. 
Iako je novostvorena formacija bila direktni naslednik žandarmerije i, po pretpostavljenoj ulozi, funkciji i strukturi, trebalo da je zameni, tek $15,66 \%$ (104) oficira je došlo iz žandarmerije. Najveći broj je dolazio iz roda pešadije $(187-28,16 \%)$, a potom su ostali rodovi bili zastupljeni sledećim redom: artiljerija $(82-12,35 \%)$, ekonomska služba $(81-12,2 \%)$, sanitet $(41-6,17 \%)$, inžinjerija $(38-5,72 \%)$, vazduhoplovstvo $(31-4,67 \%)$, konjica $(29-4,37 \%)$, sudska struka $(23-3,46 \%)$, policija $(17-2,56 \%)$, automobilska struka (10 $1,51 \%)$, mornarica $(4-0,60 \%)$, vojno sveštenstvo $(4-0,60 \%)$, muzička služba (4-0,60\%), građanstvo $(3-0,45 \%)$, vatrogasna služba $(2-0,3 \%)$ i bez podataka je bilo $4(0,60 \%)$.

Nacionalna i verska struktura pripadnika oficirskog kora je bila u skladu sa uslovima za stupanje po Uredbi o ustrojstvu. Kao što je navedeno, kandidati su morali biti srpske narodnosti i arijevskog porekla, ali su prvog uslova, po odobrenju ministra unutrašnjih poslova, mogli biti oslobođeni. Velika većina oficira, po analiziranom uzorku, bila je srpske nacionalnosti $(612-92,17 \%)$. Slovenaca je bilo 4,52\% (30), Albanaca 2,41\% (16), a 6 oficira su se izjasnili kao Rusi $(0,90 \%)$. Slična je bila i verska struktura:

Tabela 1: Verska struktura oficirskog kora Srpske državne straže

\begin{tabular}{|c|c|c|c|}
\hline Pravoslavni & Rimokatolici & Muslimani & $\begin{array}{c}\text { Gregorijanci } \\
\text { (jermenska crkva) }\end{array}$ \\
\hline 618 & 30 & 15 & 1 \\
\hline $93,07 \%$ & $4,52 \%$ & $2,26 \%$ & $0,15 \%$ \\
\hline
\end{tabular}

Po mestu rođenja, što je i logično, primetna je dominacija kadrova rođenih na području bivše Kraljevine Srbije - apsolutna većina oficira (406 $61,14 \%$ ). Znatan broj oficira je rođen i na području zapadnih krajeva, bivše Austro-Ugarske (195 - 29,37\%). Sa područja koje je nekad obuhvatala Kraljevina Crna Gora poticalo je 49 oficira, odnosno 7,38\%. U inostranstvu je rođeno 14 oficira (2,11\%), od čega u Rusiji 9 (1,36\%), Albaniji 2 (0,30\%), Nemačkoj 2 $(0,30 \%)$ i Francuskoj 1 (0,15\%).

Budući da je veliki broj školovanih oficira završio u zarobljeništvu, nedostajući broj neophodan za popunu formacije primljen je u kor SDS iz građanstva $(100-15,06 \%)$. Ostatak analiziranih oficira $(564-84,94 \%)$ imao je neku vrstu vojnog obrazovanja. Od toga je sa Nižom školom vojne akademije bilo 179 (26,96\%), na stranim vojnim akademijama se školovalo 9 (1,60\%), a neku od drugih vojnih škola (Niža škola intendantske akademije, Pešadijska podoficirska škola, Artiljerijska podoficirska škola, Vazduhoplovna podoficirska škola, Pilotska podoficirska škola, Žandarmerijska podoficirska škola, Mornarička podoficirska škola, Konjička podoficirska škola, Škola rezervnih oficira i dr.) 
imalo je 376 oficira, odnosno 56,63\%. Višu školu vojne akademije imalo je samo 19 oficira, odnosno $2,86 \%$. $^{10}$

Grafikon 1: Raspored po klasama oficira koji su završili NŠVA

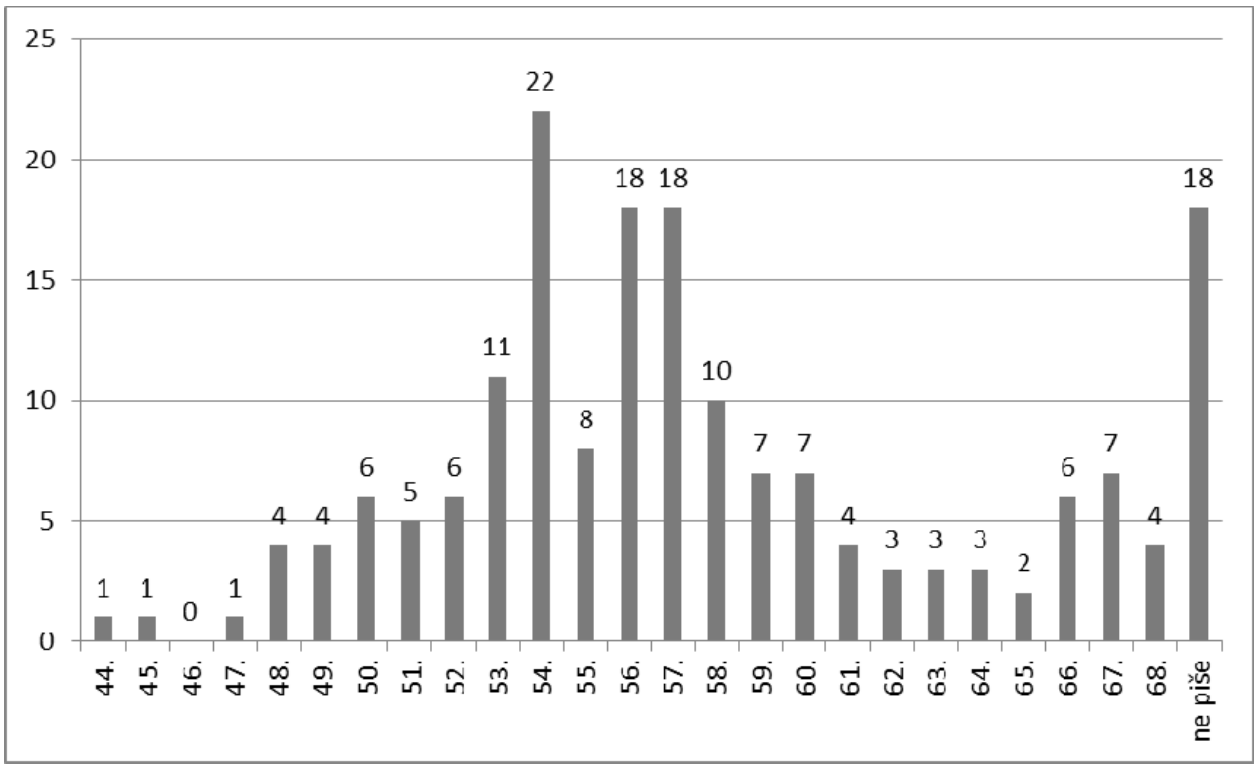

Dosijea nam daju i informaciju koju su od klasa završili oni koji su studirali na Nižoj školi vojne akademije. Kao što se može primetiti iz grafikona najviše oficira se školovalo u klasama koje su završile NŠVA u periodu 1928-1935, tj. od 53. do 60. klase $(101-56,42 \%)$. To su osobe koje su uglavnom rođene $u$ periodu 1906-1916. i do početka rata imale između 25-35 godina, iz čega zaključujemo da je najveći broj školovanih oficira bio relativno mlad. U Srpskoj državnoj straži je, u odnosu na broj promovisan na NŠVA, bio prisutan zaista mali procenat oficira. U pomenutom periodu (1928-1935) na NŠVA je promovisano ukupno 3228 oficira, a pošto je u SDS bio 101 , to je tek $3,12 \%$. ${ }^{11}$

Iako je jedan od uslova za stupanje u oficirski kor bio i da su kandidati neoženjeni, razvedeni ili udovci bez dece, stanje stvari na terenu je prinudilo

${ }^{10} \mathrm{Da}$ bi konkurisali za generalštabnu pripremu i najviše činove, oficiri su morali imati završenu Višu školu vojne akademije, a da bi nju pohađali morali su ispuniti sledeće uslove: najmanje 5 godina službe, do 32 godine starosti, najviše čin kapetana I klase, da imaju sređene materijalne prilike i da polože prijemni ispit. - Mile Bjelajac, Vojska Kraljevine SHS/Jugoslavije 1922-1935, Beograd 1994, 151-152.

${ }^{11}$ Potrebno je napomenuti da je prva posleratna klasa koja je školovanje započela oktobra 1919. bila 47. klasa. U periodu od 1919. do 1924. školovanje na NŠVA je trajalo dve godine, od 1924. dve i po, a 1928. je povećano na tri godine. - M. Bjelajac, $n$. d., 54-55, 152153. 
kolaboracionističke vlasti da taj uslov ne primenjuju. Od ukupnog broja oficira čija smo dosijea analizirali, više od dve trećine su bili oženjeni (479-72,14\%), a tek nešto više od četvrtine $(181-27,25 \%)$ ispunjavalo je ove uslove. ${ }^{12}$

Premda su većina bili oženjeni, ipak je više od polovine bilo bez dece, čak 359 (54,07\%). Jedno dete je imalo njih 129 (19,43\%), dvoje 115 (17,32\%), a troje i više dece 61 oficir $(11,11 \%)$.

Brojno stanje oficira Srpske državne straže tokom rata je variralo. Kao najpouzdanije izvore za utvrđivanje njihovog broja koristili smo nemačku izvornu građu i zvaničnu tabelu rashoda za plate, koja je navođena kao jedna od stavki u budžetu.

Krajem 1941. godine, neposredno pre formiranja SDS, u Žandarmeriji su na platnom spisku bila 663 oficira. Raspored po činovima je bio sledeći:

Tabela 2: Struktura oficira Žandarmerije po činovima krajem 1941. godine $e^{13}$

\begin{tabular}{|c|c|c|c|c|c|c|c|c|}
\hline 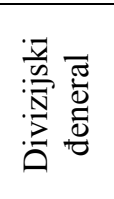 & 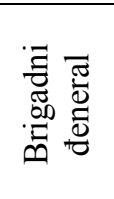 & 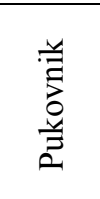 & 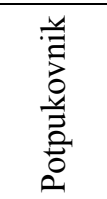 & $\frac{\stackrel{0}{\sigma}}{\Sigma}$ & 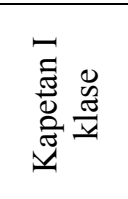 & 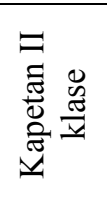 & 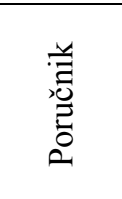 & 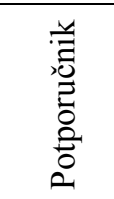 \\
\hline 1 & 2 & 15 & 15 & 30 & 69 & 65 & 262 & 204 \\
\hline $0,15 \%$ & $0,30 \%$ & $2,26 \%$ & $2,26 \%$ & $4,52 \%$ & $10,40 \%$ & $9,80 \%$ & $39,51 \%$ & $30,77 \%$ \\
\hline
\end{tabular}

Krajem februara 1942. u formaciji koja je bila direktna preteča SDS Srpskoj državnoj policiji, prema nemačkim podacima bilo je 695 oficira. ${ }^{14}$ Neposredno nakon stvaranja, 10. marta 1942. godine, SDS je trebalo da ima po formaciji 580, ali je na licu bilo 682 oficira (od čega 48 pripadnika SDS Uprave grada Beograda) i još 94 starešine SDS u Banatu, koja je direktno bila potčinjena nemačkoj okupacionoj upravi. ${ }^{15} \mathrm{Na}$ dan 15 . marta 1942, posle nove reorganizacije, SDS je imala 665 oficira. Razlika u odnosu na prethodni broj je zbog toga što su određeni pojedinci otpušteni zbog nepouzdanosti. ${ }^{16}$ I dalje kroz 1942. brojno stanje se menja, pa je 3. maja Srpska državna straža imala $610,{ }^{17}$ a 8 . juna 647 oficira. ${ }^{18} \mathrm{U}$ avgustu 1942. godine, u dva izveštaja sa početka i sredine meseca navodi se brojka od $649,{ }^{19}$ a potom na kraju meseca informacija da SDS ima 668

${ }^{12}$ Od tog broja neoženjenih je bilo 178 (26,81\%), razveden je bio $1(0,15 \%)$, dvojica su bili udovci $(0,30 \%)$, a za četvoricu $(0,60 \%)$ nisu navedeni podaci. - Vojni arhiv (VA), fond Nedićeva arhiva (NdA), kutija 141, 142 i 143.

${ }^{13}$ Službene novine, 30. decembar 1941 (Državni budžet za 1942. godinu), 121-122.

${ }^{14}$ Zbornik NOR-a, XII-2, 155.

${ }^{15}$ Isto, 215.

${ }^{16}$ Isto, 233.

${ }^{17}$ Isto, 400.

${ }^{18}$ Isto, 482.

${ }^{19}$ Isto, 604, 621, 645. 
oficira. ${ }^{20}$ Nakon izdvajanja Srpske granične straže u oktobru, na dan 5. decembra 1942. brojno stanje oficira u SDS iznosi $569 .^{21}$

U budžetu za 1943. godinu dolazi do znatnog skoka broja oficira. U predviđenim izdvajanjima za lične rashode potražuju se sredstva za 789 oficira što je uvećanje od čak 220 u odnosu na samo mesec dana ranije. ${ }^{22}$ Raspored po činovima je bio kao u tabeli koja sledi:

Tabela 3: Struktura oficira SDS po činovima početkom 1943. godine ${ }^{23}$

\begin{tabular}{|c|c|c|c|c|c|c|c|c|}
\hline $\begin{array}{l}\overline{\widetilde{T}} \\
\bar{\Xi} \\
\text { ه }\end{array}$ & $\begin{array}{l}\text { 兰 } \\
\text { 总 } \\
\text { 至 }\end{array}$ & 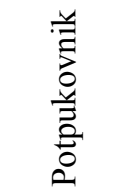 & $\frac{\stackrel{\circ}{\sigma}}{\Sigma}$ & 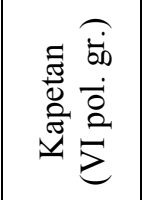 & 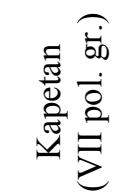 & 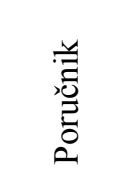 & 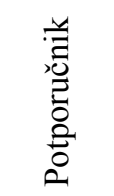 & 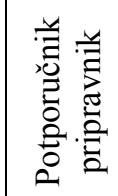 \\
\hline 1 & 16 & 34 & 62 & 281 & 182 & 128 & 77 & 0 \\
\hline $0,13 \%$ & $2,03 \%$ & $4,31 \%$ & $7,86 \%$ & $35,61 \%$ & $23,07 \%$ & $16,22 \%$ & $9,76 \%$ & \\
\hline
\end{tabular}

U budžetu za 1944. godinu broj oficira za koje se planiraju rashodi je samo neznatno promenjen i iznosi 790.

Tabela 4: Struktura oficira SDS po činovima početkom 1944. godine $e^{24}$

\begin{tabular}{|c|c|c|c|c|c|c|c|c|}
\hline $\begin{array}{l}\bar{\pi} \\
\bar{\Xi} \\
\Phi \\
\Phi\end{array}$ & $\begin{array}{l}\text { 兰 } \\
\text { 总 } \\
\text { 音 }\end{array}$ & 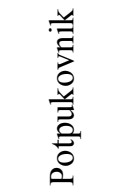 & $\frac{\tilde{\sigma}}{\Sigma}$ & 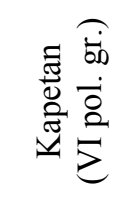 & 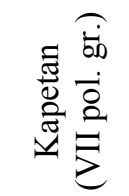 & 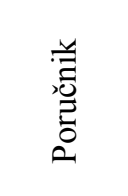 & 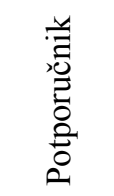 & 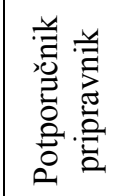 \\
\hline 2 & 14 & 34 & 61 & 257 & 196 & 146 & 71 & 9 \\
\hline $0,25 \%$ & $1,77 \%$ & $4,30 \%$ & $7,72 \%$ & $32,53 \%$ & $24,81 \%$ & $18,48 \%$ & $8,98 \%$ & \\
\hline
\end{tabular}

${ }^{20}$ Isto, 699.

21 Isto, 918 .

${ }^{22}$ Pošto je nemoguće da bi toliko uvećanje u broju oficira ostalo neprimećeno od nemačkih vlasti, pretpostavljamo da je cifra od 789 oficira za koje se traže rashodi ipak bila drugačija od stanja na terenu, za koje su nemački izveštaji pouzdaniji izvor. Pretpostavljamo da je ova razlika u stvari razlika između formacijskog i stvarnog stanja, iako nismo našli potvrdu te hipoteze u izvorima.

${ }^{23}$ Iako su Uredbom o ustrojstvu Srpske državne straže ukinuta dva kapetanska čina (kapetan I klase i kapetan II klase) i uveden samo čin kapetana, ipak je, iz praktičnih razloga, u službenim beleškama i rashodima pravljena razlika koja se označavala pripadništvom dvema različitim položajnim grupama. Tako su bivši kapetani II klase označavani kao kapetani VII položajne grupe, a oni koji su ranije nosili čin kapetana I klase označavani su kao kapetani VI položajne grupe. Iz tog razloga prenosimo u tabeli kapetanske činove razdvojeno - Službene novine, 1. januar 1943 (Državni budžet za 1943. godinu), 111-112.

${ }^{24}$ Službene novine, 1. januar 1944 (Državni budžet za 1944. godinu), 106. 
U građi nalazimo i informaciju da je broj oficira tri meseca kasnije (1. aprila 1944) ostao nepromenjen i iznosio takođe 790. U istom dokumentu se navodi i brojno stanje Srpske granične straže (213 oficira, 4.421 podoficir i 971 graničar). ${ }^{25}$

Uredbom o ustrojstvu propisan je i iznos plata oficira. Tako je predviđeno da đeneral SDS ima platu između 7.000-8.000 dinara, pukovnik 6.000-7.000, potpukovnik 5.300-6.000, major 4.800-5.300, kapetan 4.200-4.800, poručnik 3.900-4.200, potporučnik 3.600-3.900 i potporučnik-pripravnik 3.100-3.300. Variranja postoje zbog razlika u položajnoj grupi ${ }^{26} \mathrm{i}$ obaveznih periodskih povišica, koje su se dobijale posle svake treće godine efektivne službe provedene $u$ jednoj grupi. Pored plata oficirima je pripadao i porodični vanredni dodatak za dete. Takođe, kao i svi pripadnici SDS, oficiri su se državnim železnicama vozili besplatno, lečili se u državnim bolnicama i dobijali određene naknade za službena putovanja. ${ }^{27}$

U zvaničnom glasilu, Glasniku Srpske državne straže, oficirima su davana najrazličitija uputstva, počevši od načina na koji treba da se ophode prema podoficirima i stražarima. „Svoje ponašanje prema ljudstvu“, savetuje u svom članku sudski poručnik Branko J. Stanković, „oficiri moraju podesiti tako da ljudstvo stekne ubeđenje da mu je oficir $u$ istini starešina $i$ da on nije samo zato da ga goni, da viče na njega i da ga kažnjava. Ljudstvo mora u oficiru gledati ne samo svoga putovođu u službi, već i svoga prijatelja i pomagača u privatnom životu, na koga se može u svakom doba osloniti i tražiti od njega savet i pomoć". Isti autor navodi i uslove koji su potrebni svakom starešini „da stekne ljubav i poštovanje svoga ljudstva“: poznavanje ljudstva, objektivnost u radu, lični primer, čuvanje častoljublja, stalan dodir sa potčinjenim, stalno obrazovanje, ispravan postupak pri pregledima i smotrama, vođenje računa da se ne pretera sa pedantnošću i drugo. ${ }^{28}$

${ }^{25}$ VA, fond Nezavisna Država Hrvatska (NDH), 88-1-6.

${ }^{26}$ Oficiri su razvrstani po propisima Zakona o činovnicima u položajne grupe. Potporučnik-pripravnik je pripadao X ili IX pol. grupi, potporučnik IX, poručnik VIII, kapetan VII i VI, major V, potpukovnik IV/2, pukovnik IV/1 i III/2 i đeneral III/1 i II/2 pol. grupi. Službene novine, 3. mart 1942, 5.

${ }^{27}$ Službene novine, 3. mart 1942, 5. Da bi se dobila predstava o stvarnoj vrednosti ovih plata, navešćemo da je krajem juna 1942. kilogram krompira koštao 60, kilogram paradajza 100 , najlošijih šljiva 60 , boranije 50 , jedno jaje 7 , a litar mleka 35 dinara. Po proceni Komesarijata za nadnice i cene, u martu 1942. potrebna mesečna plata jedne porodice za snabdevanje po propisanim cenama je bila 8.159 dinara, a u decembru iste godine 11.226 dinara. Pošto je stvarna cena hrane bila znatno različita od propisane (po kojoj se retko mogla nabaviti), po istoj proceni, potrebna mesečna plata za snabdevanje jedne porodice po stvarnim cenama iznosila je 19.275 (mart 1942), odnosno čak 44.419 dinara (decembar 1942). - Nataša Milićević, Dušan Nikodijević, Svakodnevni život pod okupacijom 1941-1944. Iskustvo jednog Beograđanina, Beograd 2011, 24, 28.

${ }^{28}$ Ovaj članak je od uredništva označen kao zvanično uputstvo za postupanje i naznačeno je da se navedenih saveta treba u potpunosti pridržavati. - Branko J. Stanković, 
Takođe, u tri nastavka Glasnika, prvi komandant SDS general Stevan Radovanović (tada u penziji), dao je mnoštvo saveta oficirima. U tim uputstvima, na 62 strane, Radovanović je najpre počeo sa ideološko-političkim, ${ }^{29}$ dao najviše opšte stručnih, etičkih, ali i ljubavnih saveta oficirima. ${ }^{30}$

Nekoliko opštih zaključaka koji važe za sve pripadnike Srpske državne straže, pogotovo možemo podvući i za pripadnike oficirskog kora ove vojne formacije. Najpre, generalno opredeljenje velike većine pripadnika SDS je bilo rojalističko i patrijarhalno-konzervativno, što je proisticalo iz karaktera sredine iz koje su poticali i vaspitanja koje su stekli, budući da je većina odrasla na srpskom selu. Nadalje, bilo je većinski i antikomunističko, zbog sistema obrazovanja kroz koje su prolazili. Naposletku, mnoštvo izveštaja i dokumenata svedoče da je ogromna većina pripadnika SDS bila simpatizer, saradnik ili prikriveni pripadnik Jugoslovenske vojske u otadžbini, što pogotovo važi za oficire. ${ }^{31}$ To opredeljenje

„Ophođenje oficira prema podoficirima i stražarima i podoficira i stražara prema oficirima, njihov postupak prema narodu i odnos sa vlastima“, Glasnik Srpske državne straže, 4-5, 1943, str. 306-314.

${ }^{29}$ Ti saveti su bili uobičajena retorika Vlade narodnog spasa: „Oficiri Srpske državne straže moraju da imaju vazda na umu: da u našoj Otadžbini, naročito u sadašnjem vremenu, ima ljudi koji rade na štetu naše Otadžbine za tuđ račun, za račun nekakvih internacionala (komunista) ili za račun masonsko-jevrejski, bilo iz ubeđenja bilo što su zato plaćeni; ima ljudi koji bi želeli da dograbe vlast u državi radi svojih sopstvenih ciljeva, računa i koristi; ima i takvih koji za novac služe tuđinu i rade za račun ovih (špijuni) a na štetu naše Otadžbine, a ima i takvih zanešenjaka koji misle da mora da bude sve onako kako oni zamišljaju i kako bi oni hteli, pa sve što Vlada narodnog spasa radi proglašuju da ne valjda i da je to izdajnički, te idu okolo i pronose najneverovatnije vesti i laži kao čistu istinu, čime truju narod, seju nemir i neraspoloženje i narod dovode u sumnju i zabludu“. - Stevan M. Radovanović, „Pripadnici Srpske državne straže kakvi treba da su i šta treba da rade“, Glasnik Srpske državne straže, 7, 1943, str. 447.

${ }^{30}$ Radovanović je savetovao mladim oficirima da svoj seksualni nagon kontrolišu i da izbegavaju društvo pevačica, glumica, profesionalnih i „familijarnih“ bludnica koje će im doneti „prezente“ u vidu veneričnih bolesti. Ipak nije preporučivao „potpuno uzdržavanje polnog snošaja“. Po njegovom mišljenju „brak je najbolja brana koja štiti čoveka od poroka bludničenja“. Iako je isticao da je „žena zlo, ipak se ne može bez nje. Zlo je sa njom, ali još veće bez nje“. Dao je i nekoliko saveta mladim oficirima kojim motivima da se rukovode pri odabiru buduće supruge: „1) Da je devojka zdrava i od zdravih roditelja, da je skromna, čedna, dovoljno inteligentna, ali ne više od budućeg muža, da ima prijatan izgled, da je blaga i umiljata i da ume da se smeje, jer devojka koja se nikad ne smeje biće 'Ksantipa' u braku, i da je dotičnom oficiru simpatična; 2) da je devojka dobra domaćica...; 3) o ugledu devojke...; 4) o ugledu devojčinih roditelja...; 5) o imovnom stanju roditelja, s tim da veliko bogatstvo roditelja devojčinih ne sme da bude polazna tačka za brak, kao i da njihovo veliko siromaštvo isključuje brak oficira ako sam nije dovoljno bogat; 6 ) da devojka ima nešto miraza koji ne mora da bude veliki, ali treba da bude bar toliki da mladenci mogu da osnuju 'svoju kuću' i sa kojim će oficir u braku da ima bolji život nego što ga je imao kao momak". - Stevan M. Radovanović, „Kakvi treba da su i šta treba da rade pripadnici Srpske državne straže“, Glasnik Srpske državne straže, 8, 1943, str. 496-499.

${ }^{31}$ U izveštaju Milanu Nediću iz marta 1942, ministar unutrašnjih poslova Milan Aćimović navodi da je među oficirima Srpske državne straže mnogo onih koji „ispoljavaju 
će se naročito pokazati oktobra 1944, kada se Srpska državna straža uključila u JVUO kao Srpski udarni korpus.

Zbog ovakvog opredeljenja i saradnje sa JVUO mnogi oficiri Srpske državne straže su i hapšeni i streljani od strane okupatora. U svojoj knjizi o generalu Nediću, Petar Martinović navodi 65 uhapšenih i odvedenih u zarobljeništvo i 49 streljanih oficira. ${ }^{32}$

Nebojša Stambolija

THE OFFICER CORPS OF SERBIAN STATE GUARD

\section{Summary}

The SS and Police General August Meyszner overtook the duty in occupied Serbia in the beginning of 1942. Immediately after his arrival, Meysyner has initiated reorganization of security system in occupied Serbia, and worked on the creation of Serbian State Guard. Decree on organization of this formation has been made on March 3, 1942. The Serbian State Guard was defined as armed force that would act as security and police force as well as the border service. Decree has also defined terms for officer candidates. Based on 664 officer personal files it is possible to conclude that most of the officers came from the former Yugoslavian Army and that they had previous military knowledge. Most of the officers were Orthodox Serbs, although there were Slovenians and Albanians. Number of the officers varied during war between 569 at the least and 790 at the most. Their salaries weren't big and could hardly provide even enough for food for one family, since most of them were married. On the other side numerous Guard officers were covert associates of the General Mihailovic's Yugoslav Army in the Fatherland, which is why many of them were arrested and shot by Germans.

simpatije prema pokretu generala Mihailovića. I čak ne bi hteli prema njemu ili njegovim akcijama da preduzmu naređene mere...VA, NdA, 82-2-4. O velikom uplivu pripadnika JVUO u ljudstvu SDS izveštava i komandant bugarskog okupacionog korpusa general Nikolov koji, septembra 1942. godine, navodi da su na jugu Srbije postojale „dobro zakamuflirane organizacije nacionalnog pokreta Draže Mihailovića... Članovi tog pokreta skrivaju se iza službenih položaja i ovlasti. Nalaze se među rukovodstvom vladinih četnika, među oficirima Srpske državne straže, među sveštenicima, učiteljima, državnih službenicima“. - J. Tomasevich, $n$.d., 183.

${ }^{32}$ Nismo u mogućnosti da ove navode Martinovića proverimo kroz izvornu građu. Petar Martinović-Bajica, Milan Nedić, Beograd 2003, 379-383. 